\title{
Particulate-biofilm, expanded-bed technology for high-rate, low-cost wastewater treatment: nitrification
}

\author{
M. J. Dempsey ${ }^{\star \wedge}$, K. C. Lannigan* and R. J. Minall^ ${ }^{*}{ }^{*}$ Department of Biological Sciences, Faculty of \\ Science and Engineering, Manchester Metropolitan University, Chester Street, Manchester, M1 5GD, UK \\ and ^Advanced Bioprocess Development Limited, Campus Ventures Centre, Zochonis Building, Oxford \\ Road, Manchester, M13 9PL, UK. \\ Tel: +44 (0)161-247-1139, fax: +44 (0)161-247-6325, m.dempsey@mmu.ac.uk \\ Tel: +44 (0)161-276-8303, fax: +44 (0)161-273-5111, mike.dempsey@bioprocesses.co.uk
}

\begin{abstract}
The performance of a particulate-biofilm, expanded-bed process for nitrification of activated sludge final effluent (ASFE) is reported for a plant receiving mixed industrial and domestic wastewater.

The support material for the particulate-biofilms was glassy coke, to which the nitrifying bacteria attached and formed a highly active biofilm. An average nitrification rate of $1.7 \pm 0.6 \mathrm{~kg} \mathrm{~m}^{-3}$ expanded-bed $\mathrm{d}^{-1}$ was recorded during operation of the bioreactor, which had a hydraulic residence time of 15 minutes. On average, the ASFE contained $12.6 \pm 3.7 \mathrm{~g} \mathrm{~m}^{-3} \mathrm{NH}_{3}-\mathrm{N}$, which was reduced to $2.6 \pm 3.3 \mathrm{~g} \mathrm{~m}^{-3} \mathrm{NH}_{3}-\mathrm{N}$. Furthermore, transfer of $10-12 \%$ of the oxygen in air was achieved using counter-current aeration.
\end{abstract}

This investigation has demonstrated that a high rate of nitrification can be achieved with a particulatebiofilm, expanded-bed process. It has also demonstrated that the process can operate without backwashing and still remove particulate material from the ASFE feed.

Keywords: Nitrification; Particulate biofilm; Expanded bed; Fluidized bed; Wastewater treatment; Ammonia oxidation

\section{INTRODUCTION}

Legislation has been enacted in many countries to reduce the ammonia load on receiving waters. For example, the European Urban Wastewater Treatment Directive (CEC, 1991) led the Environment Agency to impose limits for ammonia discharge from sewage and other wastewater treatment works in England and Wales. These new limits are designed to raise the quality of receiving waters so that, for 
example, the River Ecosystem Class (NRA, 1994) is improved and fish populations can recover. The most cost-effective way to reduce ammonia discharges is to use biological nitrification.

In nitrification, nitrosofying-bacteria (e.g. Nitrosomonas) oxidise ammonia to nitrite and nitrofying-bacteria (e.g. Nitrobacter) oxidise the nitrite to nitrate. These bacteria obtain biochemical energy from the oxidation step, and some of this energy is used to reduce carbon dioxide to organic carbon, for incorporation into biomass. Aside from requiring a reduced nitrogen species and $\mathrm{CO}_{2}$, they also require similar nutrients to other organisms, including molecular oxygen.

In wastewater treatment, nitrifying bacteria normally have to compete for oxygen with the heterotrophic microbes responsible for BOD oxidation. For example, in fixed biofilm systems such as trickling filters, when the BOD concentration is $>20 \mathrm{~g} \mathrm{~m}^{-3}$, nitrification is limited by oxygen availability (Harremoes, 1982). It is for this reason that a separate unit operation, following a BOD reduction process such as activated sludge, is the most effective way to achieve high-rate nitrification. If nitrification is to be achieved in the same reactor as BOD reduction, then the different microbiological processes must be separated in time (e.g. extended-aeration activated sludge or sequencing batch reactor). In other words, BOD reduction dominates initially, with nitrification proceeding once most of the organic carbon has been oxidised. Obviously, using a dual-purpose reactor requires a longer residence time than the sequential use of separate unit operations.

Nitrifying bacteria are slow growing (under optimum conditions $\mathrm{T}_{\mathrm{d}}=8 \mathrm{~h}$ for Nitrosomonas, $10 \mathrm{~h}$ for Nitrobacter (Bock, Koops and Harms, 1986)) and are therefore easily washed out of conventional suspension culture systems, such as activated sludge, where the prevailing conditions often result in doubling times of 1-3 days. Thus, to operate a high-rate nitrification process, some form of biomass retention is required. Although biomass retention is the chief operational characteristic of traditional trickling filters, a high cell concentration cannot be achieved because of the large, inactive volume occupied by the biomass support material. Trickling filters typically provide a surface area for biofilm development of up to $300 \mathrm{~m}^{2} \mathrm{~m}^{-3}$ and can retain a biomass concentration in the range $0 \cdot 2-0 \cdot 4 \mathrm{~kg} \mathrm{~m}$. $\mathrm{In}$ contrast, activated sludge processes operate with 2-4 $\mathrm{kg} \mathrm{m}^{-3}$; and recirculating bed, particulate-biofilm systems (Nicolella, van Loosdrecht and Heijnen, 2000) can retain 15-30 kg m${ }^{-3}$. A static bed of $1 \mathrm{~mm}$ particles expanded by $50 \%$ provides a specific surface area of $2400 \mathrm{~m}^{2} \mathrm{~m}^{-3}$ (Figure 1); which, theoretically, allows immobilized biomass concentrations to reach $42 \mathrm{~kg} \mathrm{~m}^{-3}$ (dry weight). This calculated 
biomass hold-up assumes a $500 \mu \mathrm{m}$ thick biofilm of $80 \%$ water content, $60-80 \%$ packing of the cells in the biofilm, and $60 \%$ packing density of the particles.

Because the process was operated on activated sludge final effluent at a wastewater treatment works, it was not possible to control the chemical, physical or biological composition of our process feed. Therefore, it was not possible to perform controlled experiments and determine accurate process dynamics and kinetics for modelling purposes. It is therefore not possible to develop a universal approach to interpretation of the information at this stage in the development of our expanded bed process.

\section{MATERIALS AND METHODS}

\section{Bioreactor design}

The bioreactor was constructed from QVF glassware (QVF Process Systems, Stone, Staffordshire, UK), as shown in Figures 2 and 3. The expanded bed column was $10 \times 100 \mathrm{~cm}$, with an aeration column $5 \times$ $100 \mathrm{~cm}$. Oxygen was supplied by passing compressed air (1.9-2.1 kg cm${ }^{-2}$ gauge) at $1.5 \mathrm{dm}^{-3} \mathrm{~min}^{-1}$ (STP) through a ceramic air diffuser (MBD 75, Point Four Systems Inc., Richmond, British Colombia, Canada). Activated sludge final effluent (ASFE) was delivered (normally at a rate between $35-40 \mathrm{dm}^{-3} \mathrm{~h}^{-}$

${ }^{1}$ ) part way down the aeration column by a peristaltic pump (601S/R, later replaced with a 501S/R, Watson-Marlow, Falmouth, Cornwall, UK), so that it was drawn down with the recycle flow. This recycle flow was induced by a domestic central-heating pump (Gold 50, Wilo Salmson Pumps Ltd., Burton-onTrent, UK) and the flow rate set using a diaphragm valve, to give an upward velocity of $1 \mathrm{~cm} \mathrm{~s}^{-1}$. The upward velocity was measured by timing the rate at which the bed surface rose during re-expansion after static bed height measurement. The empty reactor volume was approximately $10 \mathrm{dm}^{3}$, thus the recycle time was about 2 minutes and the hydraulic residence time (HRT) was about 15 minutes.

It must be emphasised that there was no process control of the bioreactor; it was merely designed to test the principle of particulate-biofilm expanded-bed nitrification of ASFE. Therefore, although peaks in ammonia loading were not handled well, the investigation was not designed with this in mind. Nor was the bioreactor designed for long-term operation.

\section{Particulate biofilms}

The biomass support material was glassy coke (Dempsey, 2000), which is superior to more conventional materials, like sand. Approximately $70 \%\left(1.6 \mathrm{dm}^{3}\right)$ of the material placed into the bioreactor was pre- 
seeded in the laboratory and the balance $\left(0.6 \mathrm{dm}^{3}\right)$ was clean coke. Pre-seeding was achieved by feeding the outflow from a nitrifying, lab-scale expanded bed to a larger rig, which ensured immediate nitrifying capacity of the field-based bioreactor. The static bed height was measured by switching off the flow with an isolation valve and recording the bed height $60 \mathrm{~s}$ after initial settlement from the expanded state, so that a standard degree of compaction occurred each time. The difference between the original static bed volume (clean support particles) and the increased volume after colonisation can be used to calculate the volume of retained biomass. For this calculation, the colonised particles were assumed to pack to between $60 \%$ (solid spheres) and $80 \%$ (deformable biofilm); and the cells to pack to $60 \%$ in the biofilm, with an assumed water content of $80 \%$.

\section{Chemical analyses}

Samples of the bioreactor feed and effluent, and from below the base and above the top of the bed, were collected for off-site analysis. These samples were filter-sterilized (Acrodisc syringe filter, $0 \cdot 2 \mu \mathrm{m}$ Supor membrane, Pall, UK) and the concentrations of ammonia (hypochlorite, salicylate and nitroprusside, Method D(HMSO, 1981a)), nitrite (azo dye, Method H(HMSO, 1981b)) and nitrate (UV absorption, Method F (HMSO, 1981b)) measured spectrophotometrically. In addition, $\mathrm{pH}$, dissolved oxygen and temperature were measured on-site using portable instruments. The ASFE feed rate was determined by measuring the bioreactor effluent flow-rate, with the air-stone removed from the aeration column to avoid errors due to changes in airflow rate caused by pressure variations. Although the feed pump was normally set at one speed, the flow rate did vary because of slight changes in the inlet pressure, roller pressure and tubing wear.

\section{RESULTS AND DISCUSSION}

\section{Biofilm development}

Measurement of biofilm development is inherently difficult for expanded bed systems, owing to difficulties in obtaining representative samples. Therefore, the amount of accumulated biomass was estimated from the increase in static bed volume. The pre-colonised coke carried a thin nitrifying biofilm of $6 \cdot 6-8.8 \mathrm{~kg} \mathrm{~m}^{-3}$ (calculated for $50 \%$ bed expansion, from the static bed height increase). Given that a $500 \mu \mathrm{m}$ biofilm thickness was assumed for the calculations of biomass retention (hold-up, equivalent to MLSS for Activated Sludge) in Fig. 1, the biofilm on the pre-seeded coke was therefore approximately $80 \mu \mathrm{m}$ deep. 
Assuming spherical particles and $50 \%$ bed expansion, the biomass concentration may be empirically predicted as detailed below:

Biomass concentration in an expanded bed = Particle Volume $\mathrm{x}$ Particle Packing Proportion (0.6 for spheres) $x$ Volume of Bed at $50 \%$ expansion x Mass of Dry Biomass $(200 \mathrm{~g} / \mathrm{l}) \times$ Biomass Packing Proportion (0.6).

The biomass packing proportion of 0.6 is an underestimate, these values are based on static bed volume measurements and a soft biomass will deform to fill interstitial voids, thereby increasing this proportion. Furthermore, the calculation of biomass concentration assumes $80 \%$ water content of the biofilm, which is assumed to have the same density as water.

After 110 days, the biomass concentration had increased to $17 \cdot 6-23 \cdot 6 \mathrm{~kg} \mathrm{~m}^{-3}$, equivalent to a biofilm thickness of $200 \mu \mathrm{m}$. This increase followed colonisation of the clean coke and further growth on the preseeded coke. Once colonised, the coke became distinctly orange-brown, which is characteristic of nitrifying bacteria (clean coke is normally dark grey to black).

Owing to a high feed rate during the first three weeks of operation, flocculent material (presumed to be heterotrophic biomass) built up above the expanded coke bed. However, once the feed rate was decreased, the flocs washed out; as indicated by the static bed decrease from 41.5 to $27.5 \mathrm{~cm}$ (Figure 4). There was also an increase in the proportion and concentration of ammonia removed (Figure 5), initially from $<40 \%$ on day $22\left(\left[\mathrm{NH}_{3}-\mathrm{N}\right]_{\text {in }}=8.7 \mathrm{~g} \mathrm{~m}^{-3}\right)$, to over $70 \%$ on day $33\left(\left[\mathrm{NH}_{3}-\mathrm{N}\right]_{\text {in }}=11.4 \mathrm{~g} \mathrm{~m}^{-3}\right)$, presumably because of decreased competition for oxygen from heterotrophic microbes. Therefore, data from the first 5 weeks of operation was not characteristic of the rest of the run.

Although biofilm development was noticeable by colour and appearance, it was not measurable as an increase in bed volume during the first 7 weeks operation (discounting flocs, Fig. 4). This was because the microbes colonised the pores and rough surface of the coke first, which was detectable visually but not by increased bed height. By week 8 , the bed volume started to increase $(24 \%$ larger by week $11=$ $0.8 \% \mathrm{~d}^{-1}$ ). However, when a modification to the flow distributor was made, the bed growth rate increased to $1 \cdot 1 \% \mathrm{~d}^{-1}$ (weeks $\left.12-16\right)$.

Although severe attrition of the coke occurred during pre-seeding, when more than $22 \%$ of the original charge wore away in only 3 months (data not shown), this was not observed with the field reactor. The design change, from downward discharge into a cone (Cooper and Wheeldon, 1981) to upward 
discharge into an expansion section, was presumably responsible. It is also likely that pre-seeding the coke helped to prevent attrition, with the resilient biofilm protecting the pre-seeded support particles from direct abrasion, although some minor abrasion of the un-seeded portion of the coke might have occurred. Following a period of freezing weather (days 117-119), operational problems occurred in the AS plant and the ASFE became hard to filter-sterilize. This filtration difficulty was caused either by high molecular weight materials or by carry-over of suspended solids, and lasted for 8-10 days. However, on no occasion was the nitrified effluent from the expanded bed bioreactor difficult to filter, indicating the ability of the expanded bed process to remove this material.

At the same time, the bed became colonised by a colonial, ciliate protozoan with contractile, branching stalks. This resulted in "fluffy" biofilms, which caused a rapid increase in static bed height (from $47 \cdot 2 \mathrm{~cm}$ on day 119 to $53.5 \mathrm{~cm}$ on day 128 , Fig. 4). However, this rapid rate of growth $\left(2 \cdot 5 \% \mathrm{~d}^{-1}\right)$ was partly due to measurement artefacts, caused by an increased compaction time from the normal 60 s to more than 5 minutes. The "bulking" nature of the biofilm also caused the bed to over-expand at the selected upward velocity of $1 \mathrm{~cm} \mathrm{~s}^{-1}$. In order to prevent the bed overflowing and recycling via the aeration column and fluidising pump, the upward velocity was reduced.

An attempt was made to remove the protozoa by vigorously stirring the bed, but this failed. Starvation was then tried, by switching the feed off for $24 \mathrm{~h}$, but not much was lost. Even anaerobic operation for several hours, by cutting off the air supply, failed to remove much of the attached protozoa. Therefore, the upward velocity was increased until the bed began to recycle via the centrifugal fluidizing pump. This harsh treatment succeeded in removing the bulking biofilm and normal bed expansion was resumed. Visual observation indicated that this treatment did not remove a significant amount of the nitrifying biofilm, which formed a compact layer in close contact with the coke. From this time on, excess biofilm had to be stripped approximately every week.

Before the overgrowth by colonial protozoa, the bed operated for 17 weeks without the need for any biofilm control. This confirms that expanded beds are not clogged by suspended solids, unlike moving bed processes that require back-washing every 18-24 $\mathrm{h}$. In nitrification processes, back-washing to alleviate clogging is a problem because it also removes much of the nitrifying population, as it takes about 18-24 $\mathrm{h}$ for the cells to reproduce under the ambient conditions (Painter, 1986). 
The use of glassy coke as a biomass support material allowed a high concentration of nitrifying biomass to be retained. In turn, this allowed a high rate of nitrification to be achieved with an HRT of only 15 min. This HRT is considerably less than that of other nitrification processes, such as the 60 min for up-flow, biological aerated filters (Payraudeau, Pearce, Bigot and Wicquart, 2001).

\section{Nitrification performance}

The development of a nitrifying biofilm was observed visually (the coke became orange-brown) and by the increase in static and expanded bed heights. It was also indicated by the increases in the total concentration and percentage of ammonia removed (Fig. 5). From week 8, the average concentration removed was $9.5 \pm 2.5 \mathrm{~g} \mathrm{~m}^{-3}$ (range $\left.=3.4-14.5 \mathrm{~g} \mathrm{~m}^{-3}\right)$; whilst the average percentage removed was $81 \pm$ $20 \%$ (range $=32-100 \%$ ). As indicated by the data presented in Fig. 5, the total concentration and percentage removed increased with time, and virtually all of the highest concentrations removed were after the second modification was made to the distributor, i.e. after day 78. Aside from periods of wet weather, when the inlet ammonia concentration fell and therefore the total concentration removed fell but the percentage removal remained high, two significant events caused reduced ammonia oxidation. These periods of deterioration were marked by falls in both the concentration and percentage removed; which were caused by compressor fuse failure (and hence oxygen starvation) on days 85 and 88 ; and the onset of frosty weather on days 117-119.

Before its transfer, the pre-seeded coke was expanded by $85 \%$ and nitrifying at a rate of $1.35 \mathrm{~kg} \mathrm{~m}^{-3}$ expanded bed $\mathrm{d}^{-1}\left(0.8 \mathrm{~kg} \mathrm{~m}^{-3}\right.$ reactor $\left.\mathrm{d}^{-1}\right)$. Once transferred, the bed was nitrifying at essentially the same rate $\left(1 \cdot 23-1 \cdot 27 \mathrm{~kg} \mathrm{~m}^{-3}\right.$ expanded bed $\mathrm{d}^{-1} ; 0 \cdot 71-0.94 \mathrm{~kg} \mathrm{~m}^{-3}$ reactor $\mathrm{d}^{-1}$, days 19-21) within 3 weeks of the start of operation (Figure 6).

During the first 18 weeks, the rate of nitrification averaged $1.69 \pm 0.60 \mathrm{~kg} \mathrm{~m}^{-3}$ expanded bed $\mathrm{d}^{-1}(0 \cdot 81 \pm$ $0.22 \mathrm{~kg} \mathrm{~m}^{-3}$ reactor $\left.\mathrm{d}^{-1}\right)$ and the range was 0.82-3.36 $\mathrm{kg} \mathrm{m}^{-3}$ expanded bed $\mathrm{d}^{-1}\left(0.35-1.56 \mathrm{~kg} \mathrm{~m}^{-3}\right.$ reactor $\left.\mathrm{d}^{-1}\right)$, respectively (Table 1). Although the proportion of the inlet ammonia that was oxidised (Fig. 5) rose in parallel with the development of the nitrifying biofilm (Fig. 4), as emphasised by the four-times faster rate of decline in the outlet than the inlet ammonia concentration (Figure 7), there were also periods of reduced performance. For example, towards the end of the sampling period, the inlet ammonia concentration rose from $12.5 \mathrm{~g} \mathrm{~m}^{-3}$ on day 116 , to $17.6 \mathrm{~g} \mathrm{~m}^{-3}$ on day 119 and the proportion of ammonia removed fell from $99 \%$ to $36 \%$. This rapid decline in performance coincided with continuous heavy frost 
throughout the period, as well as the onset of filtration problems and overgrowth by colonial protozoa that were first recorded two days later. It is likely that these events were connected, and highlights the importance of maintaining a good process for BOD removal prior to nitrification. It also indicates that an expanded bed nitrification process might provide early warning of problems in such upstream biological processes. Despite the rapid decline in performance, the process recovered rapidly, so that by day 122 , when the inlet ammonia concentration was even higher than on day 119 , the removal was $97 \%$ compared to $36 \%$ (Fig. 5).

The volumetric nitrification rate recorded prior to transfer of the pre-seeded coke $\left(1.35 \mathrm{~kg} \mathrm{~m}^{-3}\right.$ expanded bed $\mathrm{d}^{-}$ ${ }^{-1}$ ) equated to a specific rate of $190-250 \mathrm{~g} \mathrm{~kg}^{-1} \mathrm{~d}^{-1}$, given the estimated expanded (85\%) bed biomass concentration of $5 \cdot 4-7 \cdot 1 \mathrm{~kg} \mathrm{~m}^{-3}$. Although the volumetric rate rose as the biofilms developed, the specific rate fell, presumably because microbes other than the pure nitrifyers grown in the lab became established in the biofilm. Thus, by day 110 , when the volumetric rate was similar $\left(1.32 \mathrm{~kg} \mathrm{~m}^{-3}\right.$ expanded bed $\mathrm{d}^{-1}$ ), the specific rate had fallen to between $62-83 \mathrm{~g} \mathrm{~kg}^{-1} \mathrm{~d}^{-1}$, given the estimated expanded bed biomass concentration of $16-21 \mathrm{~kg} \mathrm{~m}^{-3}$. Nevertheless, these specific rates were $13-130 \%$ higher than those reported in the literature (all $\mathrm{g} \mathrm{NH}_{3}-\mathrm{N} \mathrm{kg}^{-1}$ MLSS or VSS d ${ }^{-1}$ ) for an activated sludge process, 36-43 (Panswad and Polprucksa, 1998); and a membrane-separation activated sludge process, 54.7 (Zhang, Yamamoto, Ohgaki and Kamiko, 1997).

\section{Aeration}

Although aeration of the process was not optimised, it nevertheless provided a high rate of oxygen transfer for such a simple device. The average concentration of oxygen removed as the wastewater passed up through the bed was $4.85 \pm 1.00 \mathrm{~g} \mathrm{~m}^{-3}$ (range $=2 \cdot 40-6.85 \mathrm{~g} \mathrm{~m}^{-3}$, Table 1). Because the upward velocity was $1 \mathrm{~cm} \mathrm{~s}^{-1}$, the concentration of oxygen removed equated to an average oxygen transfer rate of $4 \cdot 12 \pm 0.85 \mathrm{~kg} \mathrm{~m}^{-3}$ bed $\mathrm{d}^{-1}$ (range $=2 \cdot 04-5 \cdot 82 \mathrm{~kg} \mathrm{~m}^{-3}$ bed $\mathrm{d}^{-1}$ ). An explanation for the wide range in OTR is the occasional declines in recycle flow caused by partial blockage of the control valve. Nevertheless, the oxygen transfer rate was high for this un-optimised process and compares favourably with trickling filters, $3 \mathrm{~kg} \mathrm{~m}^{-3} \mathrm{~d}^{-1}$ (Nicolella et al., 2000) and activated-sludge membrane-bioreactors, 1·7$6 \cdot 5 \mathrm{~kg} \mathrm{~m}^{-3} \mathrm{~d}^{-1}$ (Cornel, Wagner and Krause, 2001). 
It is likely that the high rate of oxygen transfer resulted from the counter-current design and low dissolved oxygen concentration of the recycled wastewater. This concentration was often close to zero, which therefore resulted in the strongest driving force for re-oxygenation, and the counter-current design maximised the air bubble residence time. These two factors led to a measured oxygen transfer efficiency (OTE) of $10-12 \%$. This is in contrast to the co-current aeration systems used for most wastewater treatment processes, where the control of dissolved oxygen (DO) at e.g. $2 \mathrm{~g} \mathrm{~m}^{-1}$, means a lower driving force for oxygenation and results in an OTE of only 3-6\%. Although the energy cost of the countercurrent aerator was high $\left(0 \cdot 1-0 \cdot 3 \mathrm{~kg} \mathrm{O} \mathrm{O}_{2} \mathrm{kw} \cdot \mathrm{h}^{-1}\right)$ compared to activated sludge processes $\left(0 \cdot 6 \mathrm{~kg} \mathrm{O} \mathrm{O}_{2} \mathrm{kw} \cdot \mathrm{h}^{-}\right.$ $\left.{ }^{1}\right)$, this was because an over-sized compressor and un-optimised system were used.

The oxygen consumption in the bioreactor can be used to calculate the amount of ammonia oxidised, assuming that each mole of ammonia requires 1.5 moles of oxygen for oxidation to nitrate (Table 2). Lower values were obtained during the early period of operation, when the feed rate was too high and a large population of heterotrophic microbes would have been out-competing the nitrifyers for oxygen. The lower than predicted removal $\left(3.4 \mathrm{~g} \mathrm{~m}^{-3}\right)$ occurred on a day when there was poor aeration and poor oxygen consumption $\left(2.4 \mathrm{~g} \mathrm{~m}^{-3}\right)$; whilst the higher than predicted rate may have been at a time when the upward velocity was higher than normal, and therefore a higher volumetric oxygen transfer rate was obtained. Alternatively, there may have been higher than normal assimilation of ammonia into biomass. The relationship between the dissolved oxygen and residual ammonia concentrations at the top of the bed was investigated. A power-law relationship was found, and the data indicated that the process was ammonia-limited below and oxygen-limited above approximately $1 \mathrm{~g} \mathrm{~m}^{-3} \mathrm{NH}_{3}-\mathrm{N}$ (Figure 8). This concentration seems surprisingly low for these relatively thick biofilms. However, this was the concentration measured at the top of the pseudo-plug flow system and therefore the concentration lower down the bed was higher. For example, it has been calculated that 0.7-2.0 (mean 1.4) $\mathrm{g} \mathrm{m}^{-3} \mathrm{NH}_{3}-\mathrm{N}$ was oxidised per pass through the bed (Table 2) and therefore the concentration will vary from 2.4 to $1.0 \mathrm{~g} \mathrm{~m}^{-}$ ${ }^{3} \mathrm{NH}_{3}-\mathrm{N}$ across the bed. This low rate-limiting ammonia concentration also indicates that most of the ammonia-oxidising bacteria were near the exterior of the biofilm or that the biofilm was sufficiently thin or permeable to give rise to the effect. For example, Beyenal and Lewandowski (2002) have clearly demonstrated that mass transport can occur within a biofilm, through water-filled channels that are often an integral part of biofilm structure. In terms of process kinetics, these observations mean that the process will operate at its maximum rate whenever the ammonia concentration at the top of the bed 
exceeds $1 \mathrm{~g} \mathrm{~m}^{-3} \mathrm{NH}_{3}-\mathrm{N}$. As this is well below most statutory discharge concentrations (consents), it means that the process can be operated at its maximum rate in most practical applications.

In any event, it means that this expanded bed process is able to remove ammonia down to $1 \mathrm{~g} \mathrm{~m}^{-3}$ before significant substrate-limitation occurs. In other words, even with the most stringent discharge consent, the process can be operated at its maximum rate. In contrast, there was only a weak correlation between the amount of oxygen consumed as the wastewater passed up through the bed and the overall rate of nitrification (Figure 9), implying that oxygen supply was not normally rate-limiting.

\section{CONCLUSIONS}

- High-rate nitrification $\left(1 \cdot 7 \pm 0.6 \mathrm{~kg} \mathrm{~m}^{-3}\right.$ expanded-bed $\left.\mathrm{d}^{-1}\right)$ can be achieved with particulate biofilms operated as an expanded bed.

- Thin, particulate biofilms have a high specific rate of activity $\left(62-83 \mathrm{~g} \mathrm{~kg}^{-1} \mathrm{~d}^{-1}\right)$.

- Glassy coke is an excellent support material for immobilization of microbial cells and retention of high biomass concentrations $\left(17 \cdot 6-23 \cdot 6 \mathrm{~kg} \mathrm{~m}^{-3}\right)$.

- Counter-current aeration is a highly efficient method of supplying oxygen to biological processes (10$12 \%$ oxygen transferred from air).

- As backwashing is normally not required, a complex ecosystem becomes established and results in the removal of suspended materials.

- Expanded bed processes are sufficiently robust to rapidly recover from gross perturbations caused by upstream failures.

- Optimisation of the bioreactor design and implementation of simple process control ought to increase further the already high rate of nitrification demonstrated by this simple, expanded bed process.

- Because the process was operated on ASFE, it was not possible to perform controlled experiments and determine accurate process dynamics and kinetics for modelling purposes. 


\section{ACKNOWLEDGEMENTS}

We would like to thank Peter Bullough and Charles Wright for technical assistance; Mick Hoult for drawing Figure 2; Dr lan Roberts and Mr Dave McCormick for encouragement and support, and METRIC Ltd. for helping fund this investigation.

\section{REFERENCES}

Beyenal, H. and Lewandowski, Z. (2002), Internal and External Mass Transfer in Biofilms Grown at Various Flow Velocities, Biotechnol. Prog., 18: 55-61

Bock, E, Koops, H-P and Harms, H (1986). Cell biology of nitrifying bacteria. pp. 17-38 in: Nitrification. JI Prosser (ed). Oxford, UK, IRL Press.

CEC (1991). Directive concerning urban wastewater treatment. (91/271/EEC). Official Journal, COUNCIL OF EUROPEAN COMMUNITIES: L135/40-52.

Cooper, PF and Wheeldon, DHV (1981). Complete treatment of sewage in a two-fluidised bed system. pp. 121-144 in: Biological Fluidised Bed Treatment of Water and Wastewater. PF Cooper and B Atkinson (ed). Chichester, UK, Ellis Horwood.

Cornel, P, Wagner, M and Krause, S (2001). Oxygen transfer rates and a-values in membrane bioreactors. pp. 220 in: Abstracts Book, 2nd World Water Congress, Berlin, IWA.

Dempsey, MJ (2000). Nitrification process. PCT Patent application WO0024682.

Harremoes, P (1982). Criteria for nitrification in fixed film reactors. Water Science and Technology 14: 167-187.

HMSO (1981a). Ammonia in Waters. Methods for the examination of waters and associated materials, HMSO.

HMSO (1981b). Oxidised Nitrogen in Waters. Methods for the examination of waters and associated materials, HMSO.

Nicolella, C, van Loosdrecht, MCM and Heijnen, SJ (2000). Particle-based biofilm reactor technology. Trends in Biotechnology 18 (7): 312-320.

NRA (1994). Water Quality Objectives: Procedures used by the National Rivers Authority for the purpose of the Surface Waters (River Ecosystem) (Classification) Regulations 1994. London, National Rivers Authority.

Painter, HA (1986). Nitrification in the treatment of sewage and waste-waters. pp. 185-211 in: Nitrification. JI Prosser (ed). Oxford, UK, IRL Press.

Panswad, T and Polprucksa, P (1998). Specific oxygen uptake, nitrification and denitrification rates of a zinc-added anoxic/oxic activated sludge process. Water Science and Technology 38 (1): 133-139.

Payraudeau, M, Pearce, AR, Goldsmith, R., Bigot, B and Wicquart, F (2001). Experience with an up-flow biological aerated filter (BAF) for tertiary treatment: from pilot trials to full scale implementation. Water Science and Technology 44 (2-3): 63-68.

Zhang, B, Yamamoto, K, Ohgaki, S and Kamiko, N (1997). Floc size distribution and bacterial activities in membrane separation activated sludge processes for small-scale wastewater treatment/reclamation. Water Science and Technology 35 (6): 37-44. 


\section{Figure legends}

Figure 1: Superficial, specific surface area (SSSA) and biomass hold-up for particulate biomass support material (Assumes 60\% packing density and $80 \%$ water content)

Figure 2: Expanded bed bioreactor design

Key: AS feed inlet (1), air inlet (2), ceramic air diffuser (3), aeration column (4), fluidizing pump (5), flow-control valve (6), expanded bed (7), top of bed (8), nitrified effluent outlet (9).

Figure 3: Expanded bed bioreactor on site

Figure 4: Changes in static and expanded bed heights during start-up

Figure 5: Changes in amount of ammonia removed during start-up

Figure 6: Changes in volumetric nitrification rates of expanded bed and whole bioreactor during start-up

Figure 7: Changes in ammonia inlet and outlet concentrations during start-up

Figure 8: Effect of the limiting ammonia concentration on oxygen uptake

Figure 9: Correlation between amount of oxygen consumed per pass and rate of nitrification 


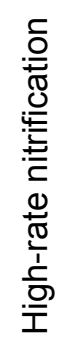

\begin{tabular}{|c|c|c|c|c|}
\hline & 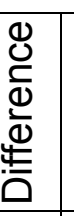 & : & $\bar{s}$ & $\begin{array}{l}b^{\prime} \\
\end{array}$ \\
\hline I $\frac{T}{\Omega}$ & ठे & 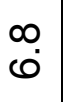 & \begin{tabular}{c}
\multirow{2}{*}{} \\
0
\end{tabular} & Qb \\
\hline & $\subseteq$ & $\check{\Gamma}$ & $\begin{array}{c}\text { an } \\
\end{array}$ & 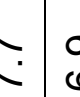 \\
\hline & 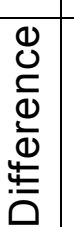 & 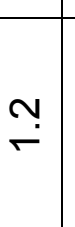 & בִ & $\stackrel{\leftrightarrow}{r}$ \\
\hline $\mid \begin{array}{l}0 \\
0 \\
0 \\
0\end{array}$ & ठे & זَ. & $\stackrel{m}{r}$ & 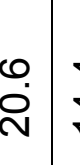 \\
\hline & $\underline{\subseteq}$ & 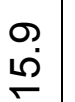 & $\stackrel{\mathbb{Y}}{\leftarrow}$ & \begin{tabular}{l}
$\underbrace{\infty}_{\infty}$ \\
\hdashline
\end{tabular} \\
\hline 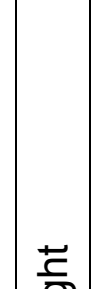 & 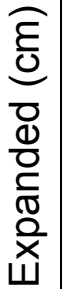 & & & $\stackrel{+\infty}{\leftarrow}$ \\
\hline 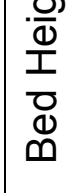 & 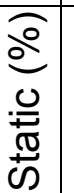 & & & $\stackrel{\text { L̊ }}{20}$ \\
\hline & 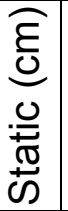 & & & 8 \\
\hline ڤ̊ํㅇ & 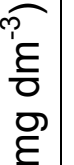 & $\stackrel{+}{\leftarrow}$ & $\rightleftarrows$ & $\stackrel{\leftrightarrow}{+} \dot{x}$ \\
\hline ه̊ & 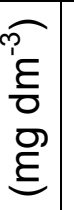 & $\begin{array}{c}\mathbf{n} \\
0\end{array}$ & : & $\begin{array}{c}\infty \\
\infty\end{array}$ \\
\hline & & 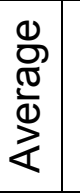 & iि & 离 \\
\hline
\end{tabular}


Table 2. Measured and Theoretical Ammonia Oxidation

\begin{tabular}{|c|c|c|c|c|c|c|}
\hline & $\begin{array}{c}\text { Measured } \mathrm{O}_{2} \\
\text { Consumption } \\
\text { per recycle }\end{array}$ & $\begin{array}{c}\text { Theoretical } \\
\mathrm{NH}_{3}-\mathrm{N} \\
\text { Consumption } \\
\text { per recycle }\end{array}$ & $\begin{array}{c}\text { Number Of } \\
\text { Recycles }\end{array}$ & $\begin{array}{c}\text { Theoretical } \\
\text { Total } \mathrm{NH}_{3}-\mathrm{N} \\
\text { consumption }\end{array}$ & $\begin{array}{c}\text { Measured } \\
\text { Total } \mathrm{NH}_{3}-\mathrm{N} \\
\text { consumption }\end{array}$ & Error \\
\hline Min & 2.4 & 0.7 & 7.5 & 5.3 & 3.4 & -1.9 \\
\hline Max & 6.9 & 2.0 & 7.5 & 15.1 & 17.6 & +2.5 \\
\hline Mean & 4.9 & 1.4 & 7.5 & 10.7 & 10.0 & -0.7 \\
\hline
\end{tabular}


Figure 1: Superficial, specific surface area (SSSA) and biomass hold-up for particulate biomass support material (Assumes $60 \%$ packing density and $80 \%$ water content)

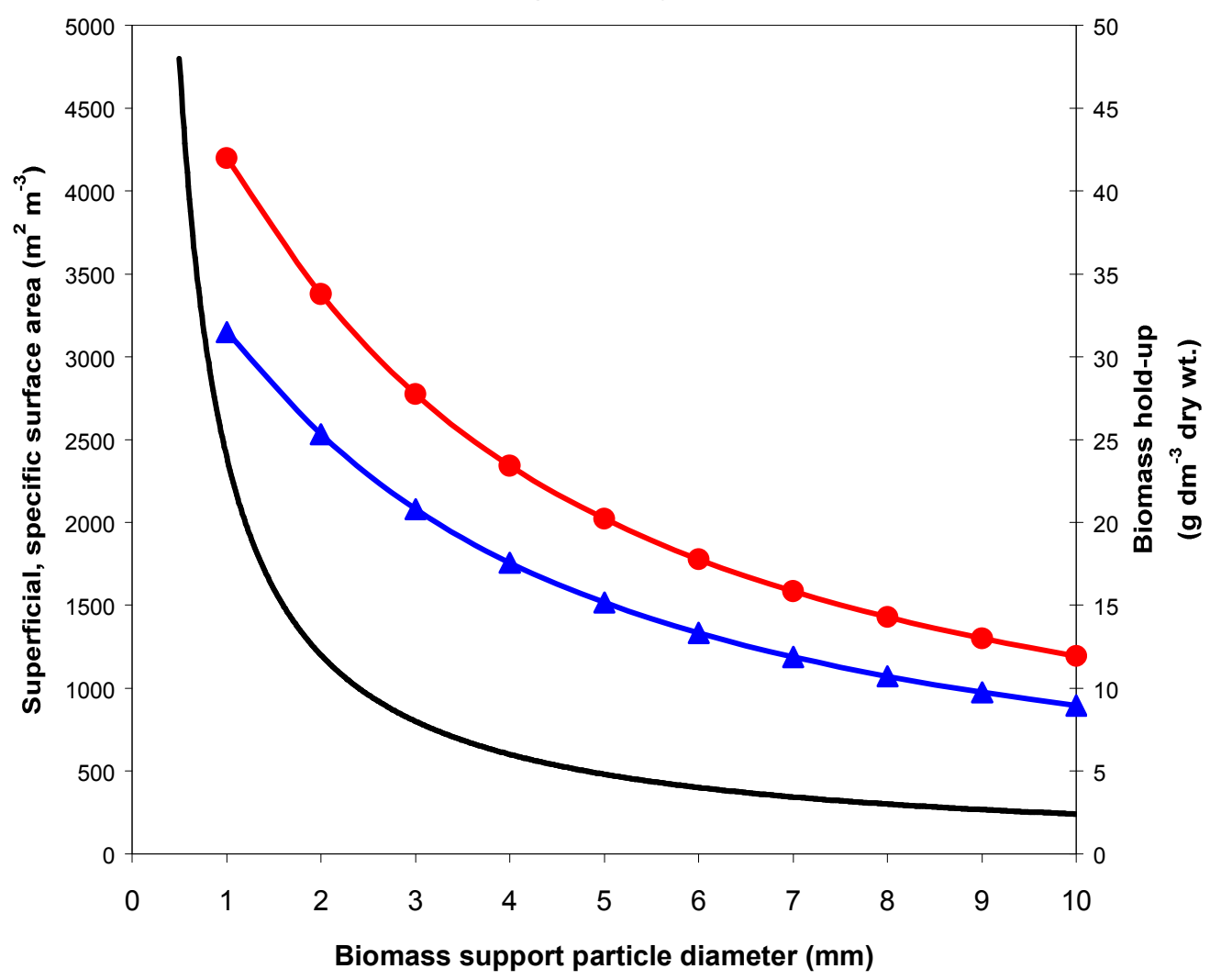

SSSA (50\% bed expansion) $\rightarrow 50 \%$ bed expansion $\leftarrow-100 \%$ bed expansion 
Figure 2: Expanded bed bioreactor design

AS feed inlet (1), air inlet (2), ceramic air diffuser (3), aeration column (4), fluidizing pump (5), flow-control valve (6), expanded bed (7), top of bed (8), nitrified effluent outlet (9).

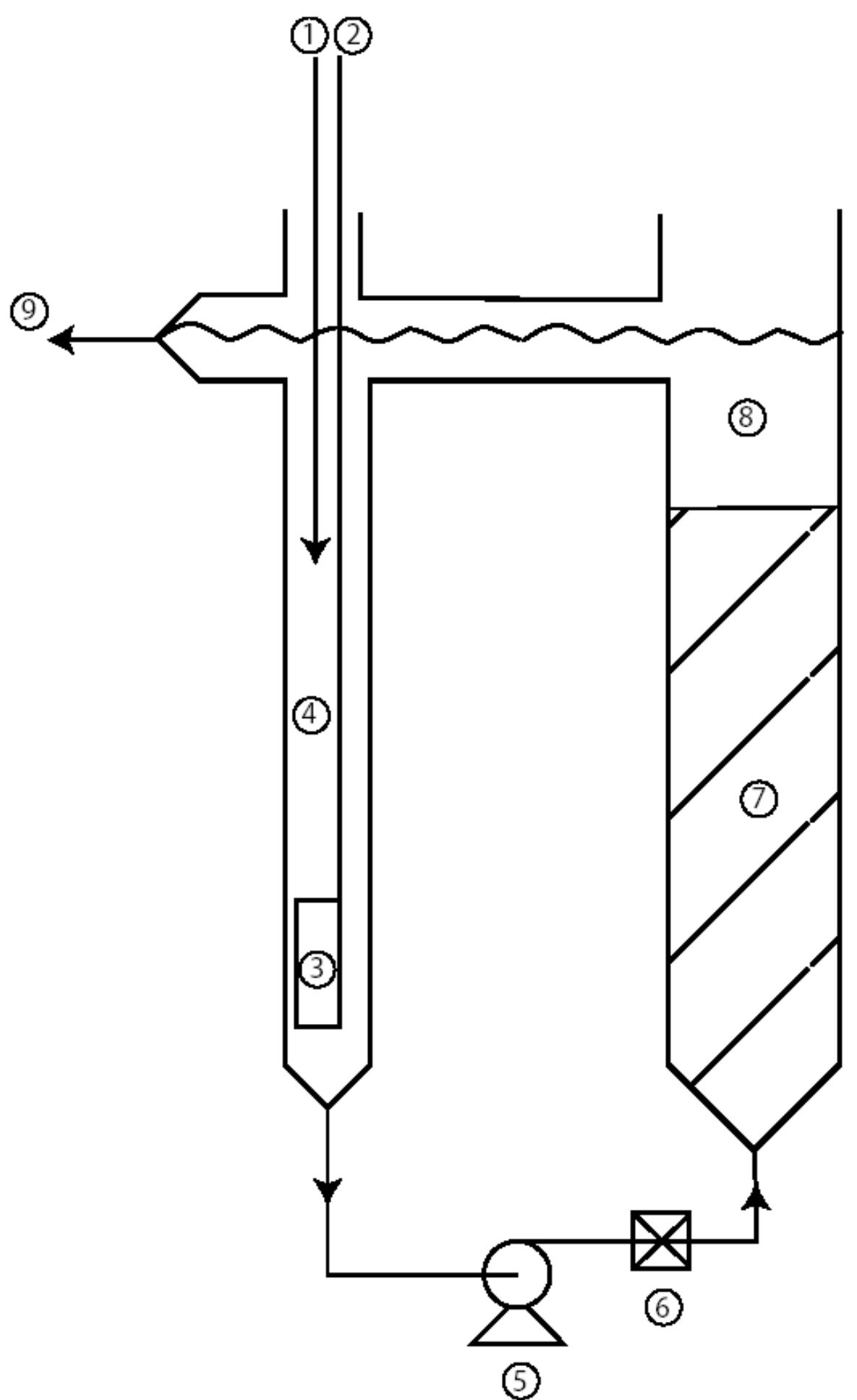


Figure 3: Expanded bed bioreactor on site

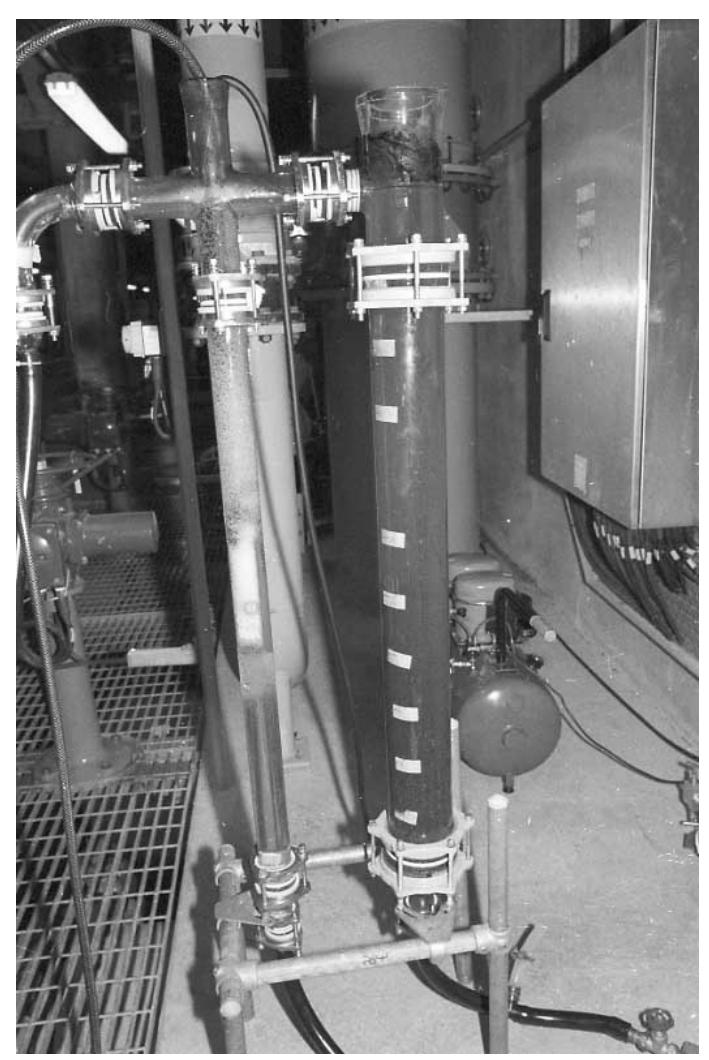


Figure 4: Changes in static and expanded bed heights during start. up

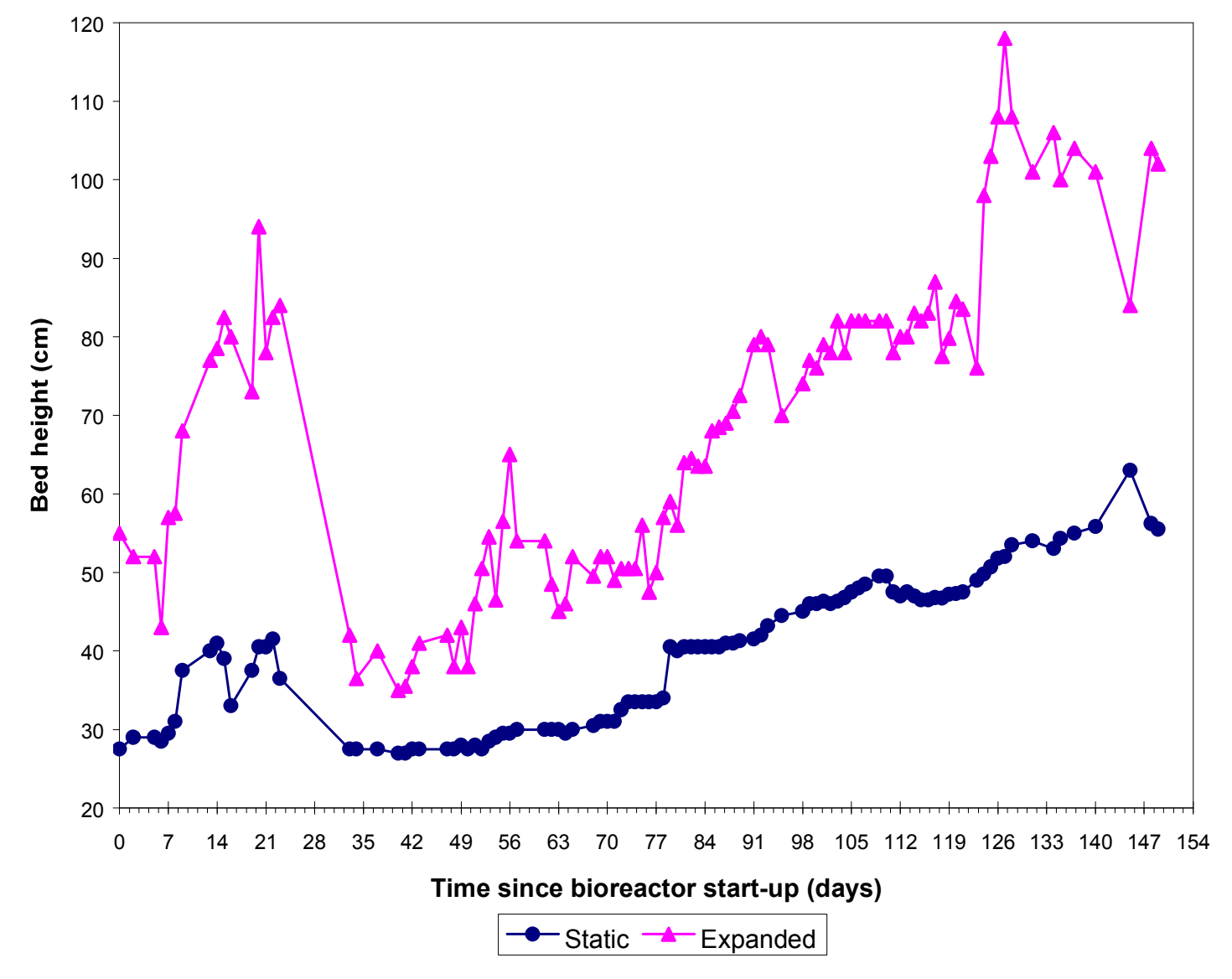


Figure 5: Changes in amount of ammonia removed during start-up

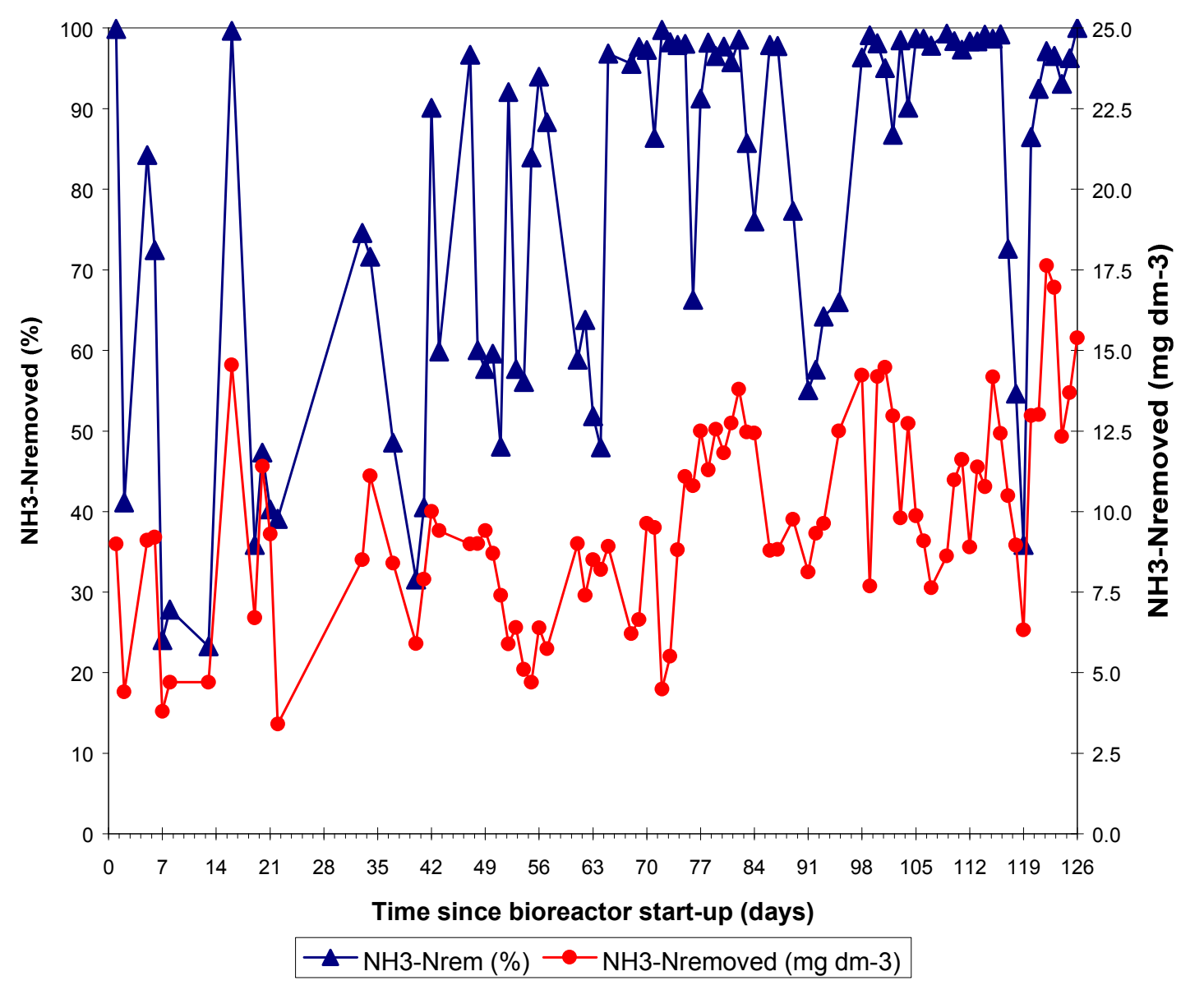




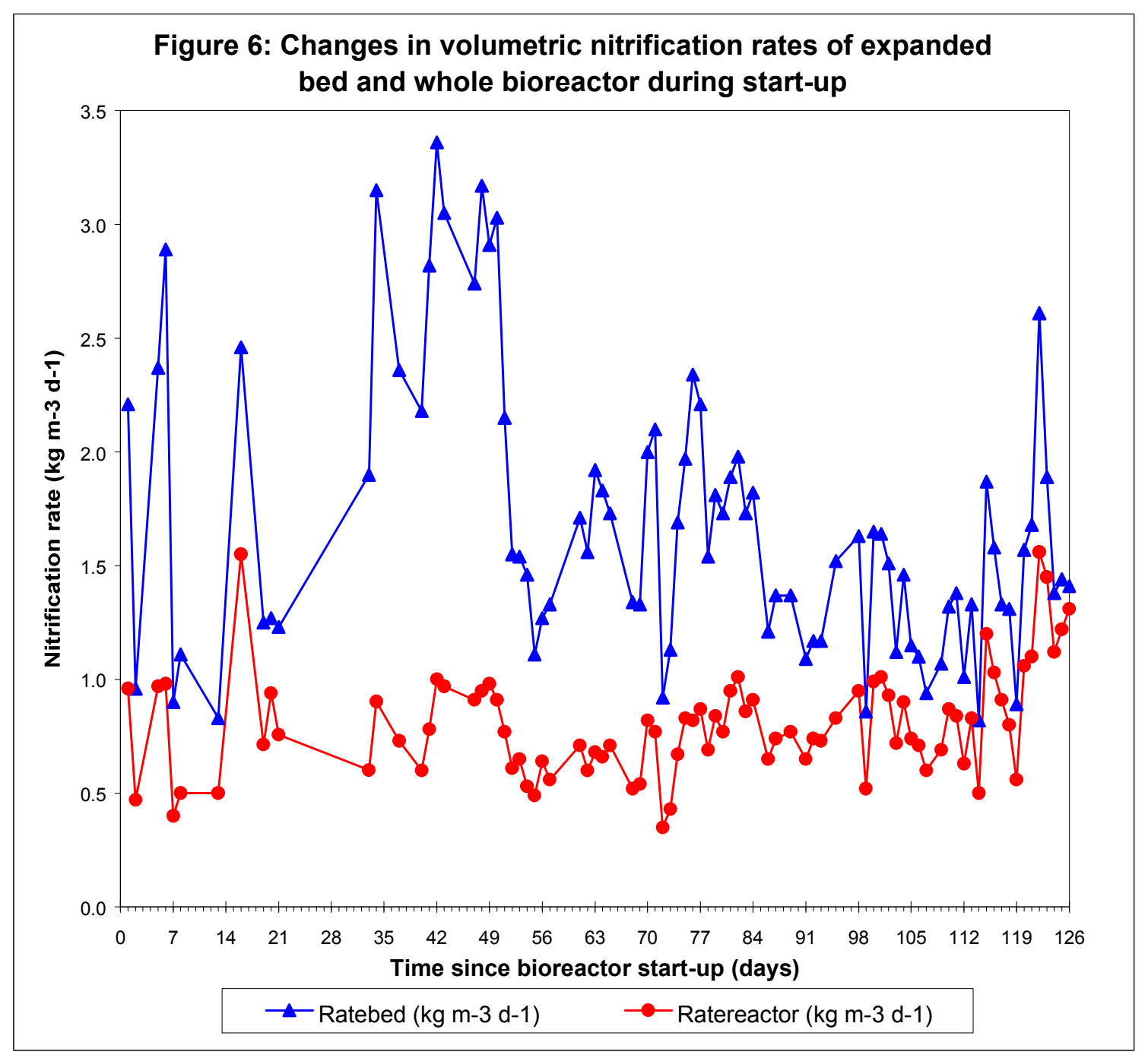




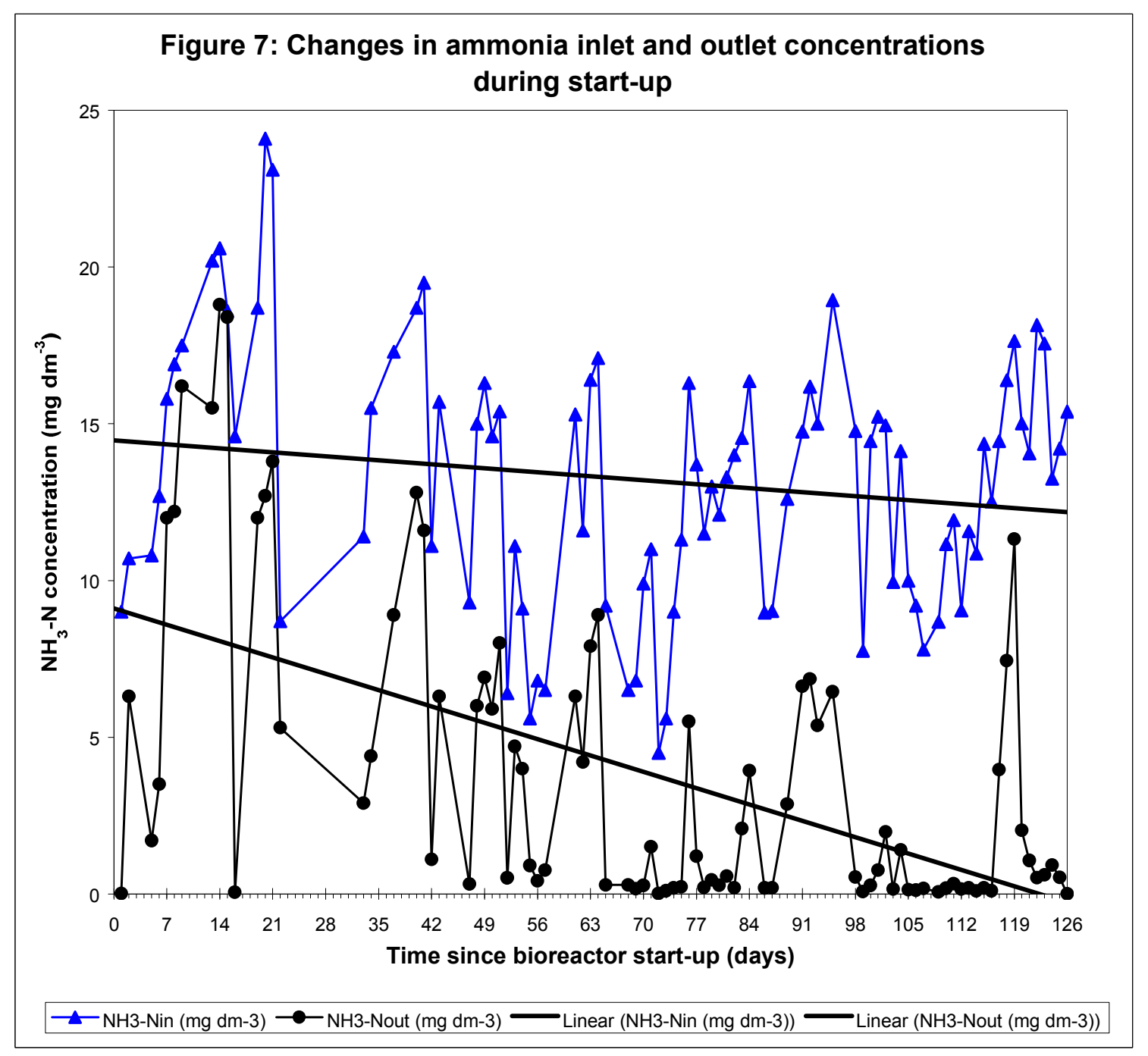




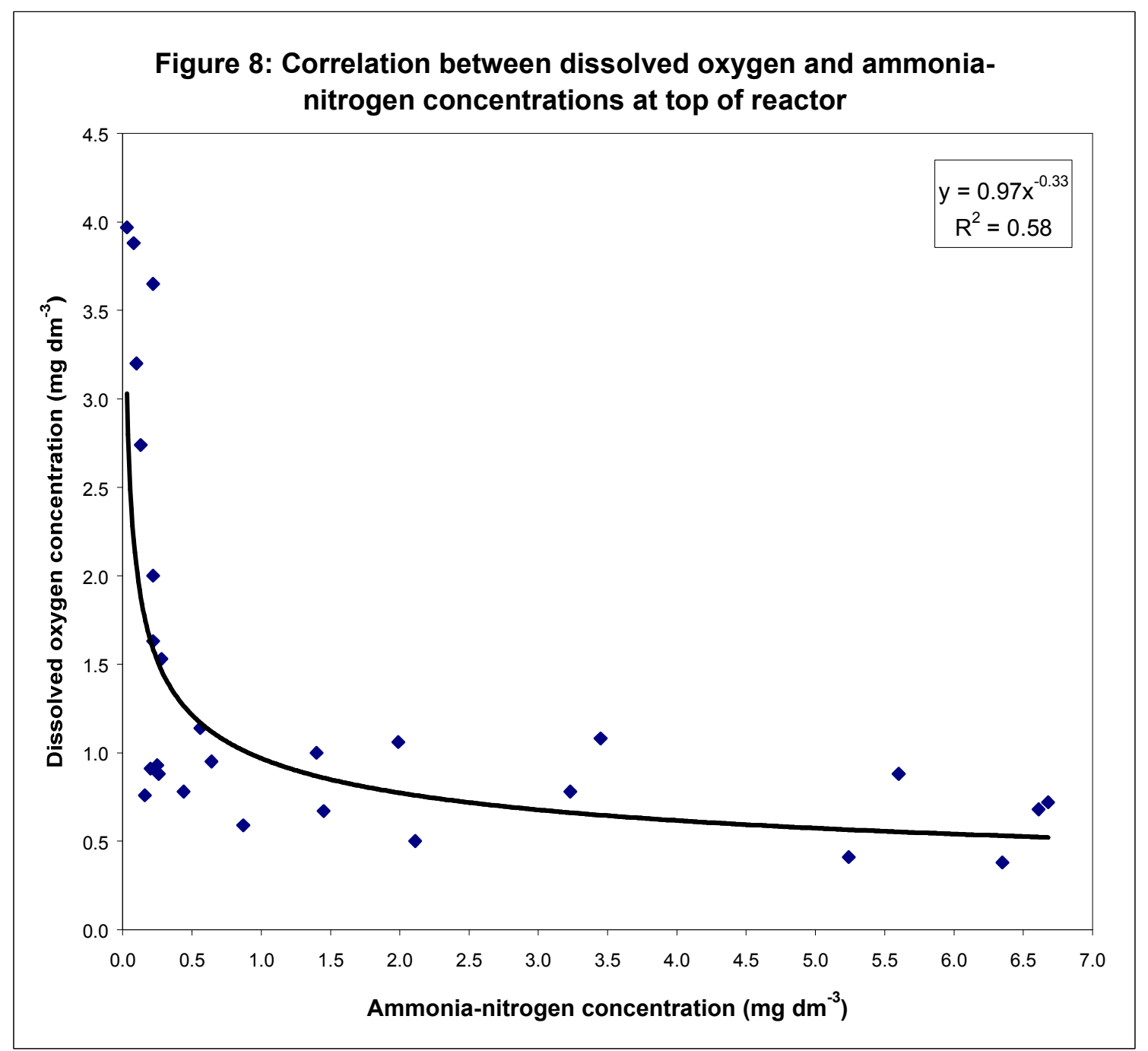




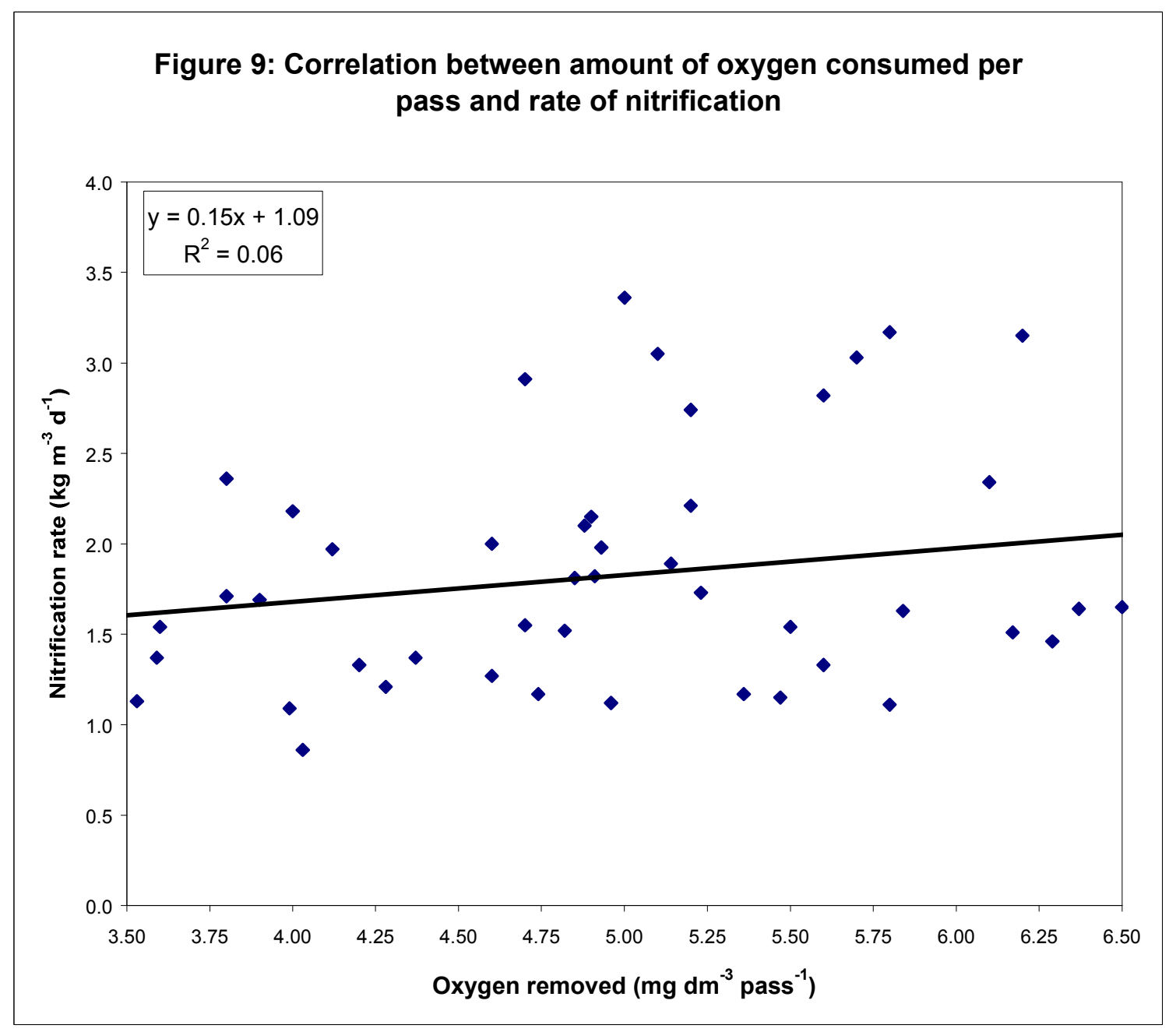

